\title{
O PROCESSO DE DESENVOLVIMENTO DE ESCRITA NO ENSINO SUPERIOR: UM OLHAR SOBREO LICENCIANDO EM LETRAS
}

\section{THE DEVELOPMENT OF WRITING SKILLS IN HIGHER EDUCATION: A GLANCE AT GRADUATING STUDENTS IN LINGUISTICS}

\author{
Elisa Cristina Amorim Ferreira' \\ Denise Lino de Araújo²
}

\begin{abstract}
RESUMO: Neste artigo, abordamos indícios da aprendizagem de escrita acadêmica em curso de licenciatura, a partir de corpus coletado com um licenciando em Letras, demandado a escrever gêneros acadêmicos durante os três primeiros períodos letivos do seu curso superior, mas sem necessariamente ter sido apresentado à estrutura prototípica, aos temas, às sequências dos gêneros solicitados ou a formas de manifestaçăo autoral. Observamos, entăo, as estratégias linguísticas usadas por esse sujeito quanto às sequências analíticas próprias da resenha, do artigo de opiniâo e do relato de observaçáo, caracterizadas pela informatividade, argumentatividade e correlaçáo com o discurso científico, por serem aquelas que revelam a inserçăo (ou năo) do sujeito na comunidade discursiva de referência. Como resultado, verificamos que a aprendizagem da escrita acadêmica deu-se em etapas a partir da apropriaçâo de especificidades da escrita nessa esfera, principalmente da unidade retórica da análise.
\end{abstract}

Palavras-chave: Aprendizagem de escrita; Escrita acadêmica; Ensino Superior

ABSTRACT: In this article, we discuss the evidence of the academic learning of writing in a Licenciate Course, with a corpus collected from an undergraduate student of Letters, who has to write academic genres during the first three semesters of his university course, but without necessarily having been presented to the structure prototype, the themes, the sequences of the requested genres or forms of authorship demonstration. We observed language strategies used by this subject as to the analytical sequences of the review, the article of opinion and the observation report, characterized by informativeness, argumentativity and correlation with the scientific discourse, because they are the ones that reveal the inclusion (or not) of the subject in the discursive community of reference. As a result, we found that the learning of academic writing took place in stages ranging from specific appropriation of writing in this sphere, especially the rhetoric unit of analysis.

Mestra em Linguagem e Ensino pela Universidade Federal de Campina Grande. Atualmente é professora da Universidade Estadual da Paraíba (Campina Grande - PB) e professora de educaçáo básica do Estado da Paraíba. E-mail: elisacristina@msn.com

2 Doutora em Educaçăo pela Universidade de Săo Paulo. Atualmente é professora da Universidade Federal de Campina Grande (Campina Grande - PB).E-mail: deniselinoaraujo@gmail.com 
Keywords: Learning Writing; Academic writing; Higher Education

\section{INTRODUÇÃO}

A aprendizagem de especificidades da escrita acadêmica em gêneros textuais típicos dessa esfera discursiva e a aprendizagem da língua escrita de prestígio săo duas perspectivas de observaçáo relacionadas da aprendizagem da língua escrita em contexto de ensino superior. Isso porque existem especificidades da escrita acadêmica, materializada nos gêneros textuais do meio acadêmico, que precisam ser aprendidas nesse nível de ensino (cf. BRONCKART, 2006; SWALES, 2009) por estarem ligadas ao domínio de determinados conhecimentos (cf. BEAUFORT, 1998 apud SWALES, 2009, p. 35; TARDY, 2009 apud BAWARSHI; REIFF, 2003, p. 164). E, porque existe uma série de problemas relacionados à aquisiçâo de escrita propriamente dita (usos da norma, por exemplo) que náo está sendo resolvida na educaçăo básica, necessitando ser sistematizado no ensino superior. Aprender a escrever significa, portanto, produzir textos especializados, coerentes com o assunto, com o processo de escrita, com o gênero, e, consequentemente, com a comunidade discursiva.

Nesse contexto em que a universidade é uma comunidade discursiva na qual o licenciando busca construir vínculo de pertencimento através da aprendizagem da escrita acadêmica, materializada em gêneros textuais, a resenha, o artigo científico e o relato de observaçáo, recorrentemente solicitados pelos professores aos graduandos, permitem observar processos dessa aprendizagem.

Assim, partindo da análise desses gêneros produzidos por licenciando em Letras de uma universidade pública, numa perspectiva longitudinal, neste artigo, buscamos investigar um processo representativo dessa aprendizagem, respondendo a seguinte questăo norteadora: "que conhecimentos para o texto especializado săo mobilizados no processo de aprendizagem da escrita acadêmica materializada nos gêneros textuais acadêmicos resenha, artigo científico e relato de observaçăo?". Em decorrência, objetivamos identificar e analisar os conhecimentos para o texto especializado mobilizados no processo de aprendizagem da escrita acadêmica por um sujeito licenciando em Letras. ${ }^{3}$

A investigaçấo aqui relatada insere-se no campo da Linguística Aplicada e caracteriza-se como uma pesquisa de natureza qualitativa longitudinal de viés documental, uma vez que averiguou textos produzidos em três períodos letivos por um sujeito licenciando em Letras de uma universidade federal que vivenciou duas mudanças expressivas, concomitantemente, a saber: (1) a turma dos alunos (turma 2011.1) foi a primeira a ingressar na instituiçăo de ensino superior citada, exclusivamente pelo ENEM, que substituiu o seu vestibular como forma de avaliaçấo e seleçăo; e (2) foi a primeira turma a ser regida pelo novo Projeto Pedagógico do Curso(PPC) de Licenciatura Letras em referência (UAL, 2011).

Esse sujeito e sua turma inauguraram uma nova fase na instituiçăo, sobre a qual năo se tinha memória: uma fase caracterizada por um exame seletivo externo que requer pouca escrita, apenas a prova de redaçăo. Além disso, ao serem os primeiros

3 Este artigo constitui um recorte de uma pesquisa maior intitulada "Desenvolvimento da escrita na academia: investigaçăo longitudinal do percurso de licenciandos em letras". 
a colocarem em andamento o novo PPC, inauguraram um novo momento da Unidade Acadêmica de Letras, na qual o curso passa a ter maior ênfase teórico-prática, baseado na exigência de escrita "constante", através, por exemplo, de quatro relatórios de estágio e uma monografia de conclusăo de curso, além dos trabalhos solicitados em cada disciplina.

O sujeito que se disponibilizou a participar da pesquisa é, do ponto de vista metodológico, o que se pode chamar de sujeito năo "contaminado", já que năo há efeito retroativo sobre ele, seja sobre o processo seletivo, seja sobre as disciplinas que estava cursando.

Nesse contexto, ao aprender a escrever para a academia, o sujeito licenciando foi demandado a escrever gêneros acadêmicos durante os três primeiros períodos letivos do curso superior, mas sem necessariamente terem sido apresentados à estrutura prototípica, aos temas, às sequências dos gêneros solicitados ou a formas de manifestaçấo autoral. Essas produçôes deram origem a quatro grupos de dados: a resenha 1 foi produzida em disciplina sobre prática educativa (2011.1), com base nos textos-fonte Sacristán e Pérez-Gómez (2000), Perrenoud (2010) e Saujat (2004)4, discutidos em sala de aula; a resenha 2 foi elaborada em um curso de escrita acadêmica realizado nas férias, entre os períodos de 2011.1 e 2011.2, organizado pela professora da disciplina citada e sua estagiária docente de ensino superior, e teve como texto-fonte Diniz Pereira(2006)5, já discutido nas aulas da disciplina citada; o artigo científico foi produzido em disciplina sobre leitura e escrita, em 2011.2, após discussóes teóricas de textos diversos; e, por fim, o relato de observaçâo foi escrito em disciplina sobre paradigmas de ensino, em 2012.1, resultante de discussōes teóricas variadas e de observaçấo feita pelo sujeito de aulas do ensino básico em escola regular.

De posse das produçōes, realizamos análise preliminar com o objetivo de estabelecer semelhanças entre elas e, com isso, possibilitar uma visăo longitudinal da aprendizagem da escrita por parte do sujeito. Para essa investigaçăo, reportamo-nos à organizaçăo retórica dos textos produzidos, ou seja, à estrutura prototípica que diz respeito ao conhecimento do gênero. Uma metodologia importante para analisá-la foi o modelo CARS (SWALES, 1990), cuja aplicabilidade, com suas devidas adaptaçôes, permitiu a observaçăo de regularidade dos movimentos retóricos na composiçăo textual dos gêneros, dentre eles, o movimento retórico de análise focalizado neste artigo. Dentro dessa metodologia, tomamos: a resenha conforme a adaptaçăo do modelo CARS (SWALES, 1990) realizada por Motta-Roth (1995) e revista por Bezerra (2009); o artigo científico de acordo com o modelo CARS da introduçâo de artigos (SWALES, 1990),

SACRISTAN, J.G; PÉREZ-GOMEZ, A. Funçôes sociais da escola: da reproduçāo à reconstruçâo crítica do conhecimento e da experiência. In. . Compreender e transformar o ensino. Porto Alegre: Artmed, 2000. . A funçâo e formaçáo do professor/a no ensino para a compreensăo: diferentes perspectivas. In. Compreender e transformar o ensino. Porto Alegre: Artmed, 2000.

PERRENOUD, P. Administrar sua formaçăo contínua. In. __. Dez novas competências para ensinar e administrar sua própria formaçâo contínua. Porto Alegre: Artmed Editora, 2010.

SAUJAT, F. O ensino como um trabalho. In. __. O trabalhado do professor nas pesquisas em educaçăo: um panorama. Londrina: Eduel, 2004.

5 DINIZ-PEREIRA, J. Formaçâo de Professores - pesquisa, representaçôes e poder. 2 ed. Belo Horizonte: Autêntica, 2006. 
aliado aos modelos de Motta-Roth e Hendges (2010) e de Lim (2006 apud MOTTA-ROTH; HENDGES, 2010. p.115); e o relato de experiência segundo o modelo desenvolvido por Silva (2002, p. 31).

Conforme esses estudos, podemos resumir as unidades retóricas básicas de cada gênero: a resenha requer resumo e comentário; o artigo científico tem unidades ligadas à descriçấo da metodologia, à exposiçăo da fundamentaçâo teórica e à análise de dados; e o relato de observaçâo tem unidades de descriçâo de uma situaçăo e sua análise; ambas correlacionadas com fundamentos teóricos, escritos à semelhança de uma resenha. Vejamos, no Gráficol, os três gêneros com suas principais unidades retóricas representados em colunas verticais:

\section{Gráfico 1: Unidades retóricas básicas dos três gêneros e suas relações}

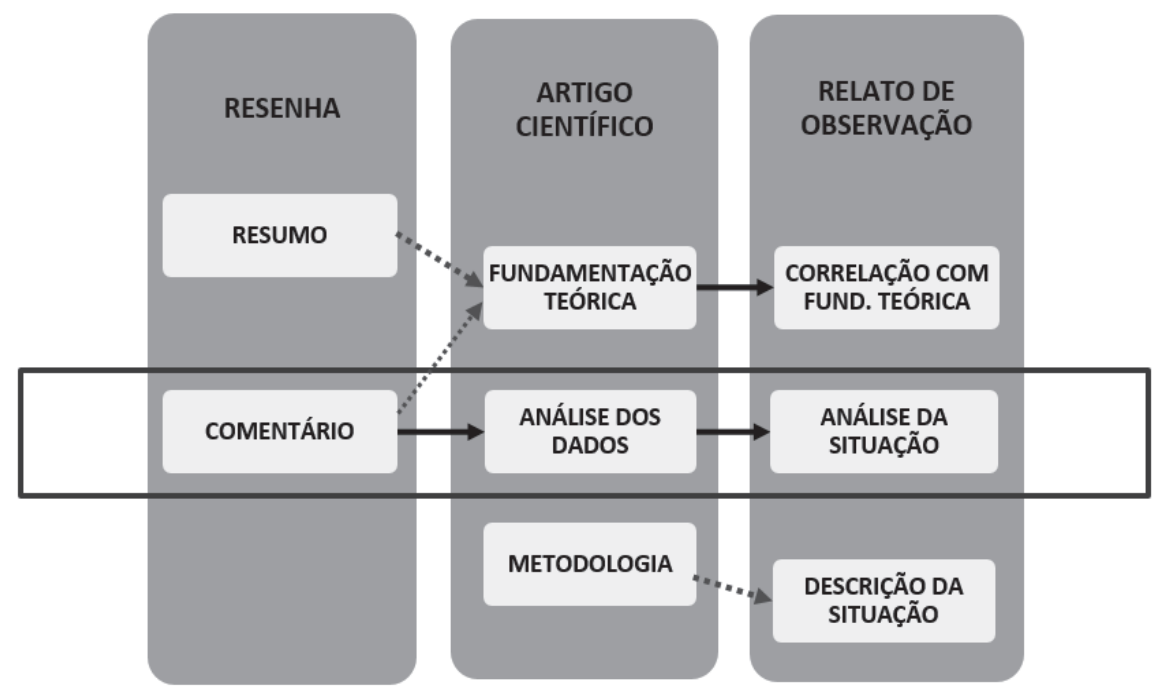

Fonte: Elaborado pelas autoras.

Ao compararmos as unidades, verificamos que ao escrever o gênero resenha (primeira coluna), no primeiro e no segundo momentos de coleta de dados, ao menos teoricamente, o sujeito desenvolveu conhecimentos ligados ao resumo e ao comentário que o auxiliou indiretamente a produçăo da fundamentaçăo teórica do artigo científico, que é uma espécie de resenha, por exigir sumarizaçăo e comentário/avaliaçăo/posicionamento; e o comentário o auxiliou a produçấo da análise dos dados do artigo científico. A produçăo desse gênero (descrito na segunda coluna), no terceiro momento de coleta de dados, por sua vez, pode ter sido influenciado pela resenha, e esta produçấo colaborou para a produçáo do relato de observaçâo (terceira coluna).

O gráfico revela, assim, um eixo comum, com suas devidas particularidades, entre a resenha, o artigo científico e o relato de observaçăo: o comentário avaliativo fundamentado, chamado comumente de "análise", sinalizado no gráfico pelo retângulo circundante. Esse eixo nos parece ser a linha comum e caracterizadora da escrita na comunidade acadêmica, a produçāo da análise. Portanto, é o domínio dessa "linha" que estabelece a pertença à comunidade discursiva acadêmica, já que, através dela, o sujeito produtor do texto posiciona-se como especialista, de acordo com uma determinada 
base teórica e uma base de dados. Em decorrência disso, selecionamos as unidades retóricas de análise de cada um dos gêneros para nossa investigaçăo.

A fim de atender ao objetivo de descrever essa pesquisa, este artigo foi estruturado a partir do seguinte plano organizacional: a presente introduçâo que apresenta breve contextualizaçăo da pesquisa; a seçâo teórica, na qual apresentamos nosso enquadramento teórico (estudos linguístico-retóricos para a aprendizagem de escrita na academia); a seçâo analítica, na qual tecemos consideraçōes sobre o percurso do sujeito através da análise de quatro produçōes textuais, com foco na unidade retórica de análise; e as consideraçóes finais, seguidas das referências.

\section{ESCREVENDO NO ENSINO SUPERIOR:PRINCÍPIOS DOS ESTUDOS LINGUÍSTICO-RETÓRICOS PARA A APRENDIZAGEM DE ESCRITA}

Os estudos linguístico-retóricos ${ }^{6}$ refletem, em parte, a revitalizaçăo da retórica clássica que resultou na nova retórica, conhecida pela preocupaçăo pedagógica com o ensino das estratégias argumentativas que melhor se adaptam ao tipo de público-alvo que se pretende convencer. Suas contribuiçōes teórico-metodológicas sâo decorrentes da preocupaçáo com o ensino/aprendizagem de língua materna (inicialmente em inglês) para fins específicos, de modo que vêm sendo adaptadas para o estudo de gêneros em contextos acadêmicos e profissionais, em diversos países, entre eles, o Brasil, com maior força nas últimas décadas.

Essa base teórica traz contribuiçóes significativas para as pesquisas na perspectiva de gênero textual indissociavelmente ligadas à situaçăo de produçăo. As definiçóes de gênero e comunidade discursiva apresentadas por estudiosos, como Swales (1990) e Miller (2009), sâo exemplos dessas contribuiçóes e foram cunhadas mantendo uma unidade de reflexăo baseada em aspectos retóricos e sociais. Assim, ao adotá-la, consequentemente, consideramos suas contribuiçóes importantes para os estudos sobre o texto escrito e compreendemos gênero textual como materializaçăo de um conteúdo temático, precedido por uma organizaçâo retórica que seleciona certas formas linguísticas, em funçăo de objetivos comunicativos compartilhados pelas pessoas envolvidas em atividades sociais específicas e contextualizadas.

A concepçâo de gênero baseia-se, assim, na prática retórica, nas convençôes de discurso estabelecidas pela sociedade como formas de "agir junto" (MILLER, 2009, p.41). O contexto é essencial para se entender e interpretar um texto e os elementos linguísticos em si nâo sâo suficientes para análise, produçâao e/ou uso de um gênero.

Já comunidade discursiva, conforme os conceitos de Swales (1992 apud BIASIRODRIGUES; HEMAIS; ARAÚJO, 2009, p. 24) e de Miller (2009), pode ser definida como projeçăo discursiva, construto retórico que persiste como aspecto estruturador de todas as formas de açâo sociorretórica, logo, é um conjunto de objetivos ou interesses compartilhados por membros do grupo que possuem mecanismos de comunicaçấo, gêneros, léxico próprio. Além disso, é composta por membros experientes, com conhecimento

Utilizamos o termo estudos linguístico-retóricos a fim de evidenciar as possíveis interconexóes existentes entre as abordagens linguísticas (ESP - inglês para fins específicos, particularmente) e retóricas de gênero (ERG). 
do discurso e do conteúdo privilegiado, e membros novatos que buscam construir esse conhecimento para participarem plenamente das atividades da comunidade.

Gênero e comunidade discursiva săo conceitos intrinsecamente relacionados, pois os gêneros estabelecem-se nas comunidades. Os gêneros textuais pertencem năo a indivíduos isolados e, sim, a comunidades discursivas compostas por grupos de indivíduos, que geram convençôes restritivas às escolhas individuais (cf. BIASI-RODRIGUES; HEMAIS; ARAÚJO, 2009). Compartilhando essa ideia, Miller (2009, p. 31) afirma que "a comunicaçâo bem sucedida requer que os participantes compartilhem tipos comuns; [e] isso é possível na medida em que os tipos săo criados socialmente". Isso implica dizer que os gêneros (formas tipificadas de discurso), produzidos por um sujeito, só sāo reconhecíveis por outro sujeito em uma situaçâo tipificada porque os gêneros săo sociais.

Os conceitos de gênero textual e comunidade discursiva săo importantes para a nossa investigaçăo, assim como os outros postulados dos estudos linguístico-retóricos, visto que a academia corresponde ao que Swales (1990; 1998 apud BONINI; FIGUEIREDO, 2010) define como comunidade discursiva ou "rede sociorretórica". Assim, a academia seria um grupo de pertença no qual o sujeito licenciando busca construir laços de pertencimento através da apropriaçăo da escrita acadêmica, materializada nos gêneros textuais típicos envolvidos nos eventos comunicativos e que săo responsáveis, em parte, pela constituiçăo e funcionamento de comunidades específicas.

No meio acadêmico, os sujeitos inevitavelmente participam de eventos comunicativos e dos fatos sociais nos quais esses eventos sâo produzidos. Esses fatos, de acordo com Bazerman (2005, p.22), sâo "açóes sociais significativas realizadas pela linguagem" que năo podem existir se as pessoas nâo os realizarem através de textos.

Por exemplo, o sujeito por nós investigado produziu gêneros, criando, com isso, um conjunto de gêneros intimamente ligado ao conjunto de gêneros dos professores das disciplinas, constituindo um sistema de gêneros que é parte do sistema de atividades acadêmicas. Cada um desses gêneros, ao ser produzido, estabelece condiçōes que, de alguma maneira, săo levadas em consideraçăo nas produçóes posteriores, criando o que nós podemos chamar de uma memória de histórico de escrita. Isso porque há características de um gênero que perpassam outros gêneros e, se um texto funciona bem numa dada situaçăo, em uma situaçăo similar, o sujeito produtor tende a escrever também de maneira similar.

A produçăo de texto, nessa perspectiva, é uma atividade social ou "sociopsicológica" (cf. BAZERMAN, 2006) que se realiza conforme convençôes discursivas especificas e revela comportamento social e conhecimento dos membros do grupo, sendo o ingresso e a ascensấo de um sujeito/membro dependente do domínio dos gêneros da comunidade, "uma vez que eles [os gêneros] sâo peças centrais na realizaçăo dos propósitos sociais estabelecidos nesse contexto" (BONINI; FIGUEIREDO, 2010, p.123).

Em cada comunidade, conhecer um gênero, segundo Bawarshi e Reiff (2013), requer ter o conhecimento de traços formais; dos propósitos a que o gênero serve; das negociaçôes das intençôes individuais na relaçăo com as expectativas e motivaçóes sociais dos gêneros; do quando, por que e onde usar o gênero; das relaçóes leitor com escritor e das relaçóes entre gêneros. Em nossa análise, portanto, investigamos a aprendizagem do gênero por parte de um sujeito; tal conhecimento năo se refere apenas ao seu reconhecimento, mas também à aprendizagem da competência para 
usar o gênero, esta, por sua vez, está ligada à produçăo, organizaçăo e vivência da ação sociorretórica.

Desse modo, o neófito em uma comunidade discursiva precisa, como lembra Bazerman (2006), entender as pressuposiçôes e os objetivos fundamentais da comunidade para desenvolver a habilidade de escrever metacognitivamente, isso é, "saber o que está fazendo" e "fazer escolhas inteligentes" (BAZERMAN, 2006, p.63) no âmbito da comunidade discursiva. Objetivos e pressuposiçóes que, para nós, estăo ligadas à compreensâo da totalidade da interaçấo dos eventos comunicativos existentes na academia (atividades em sala de aula, grupos de pesquisa e de trabalho, congressos acadêmicos, palestras, lançamentos de livros, publicaçóes de artigos.), inclusive dos sujeitos envolvidos nesses eventos (professores, pesquisadores, colegas, coordenadores, editores.). Compreender essas relaçóes parece possibilitar o entendimento de que cada texto tem um papel nessa rede, delimitando as atividades do grupo social, e que vários textos resultam dos anteriores e influenciarăo os textos posteriores, numa relaçăo intertextual infinita.

O grupo de pertença acadêmico, assim, fecha-se ainda mais se pensarmos nas especificidades discursivas de cada curso universitário, isto é, em cada instância discursiva. Sobre essa relaçáo, Wilson (2009, p.99) assegura que "no contexto acadêmico, especificamente, a aquisiçăo de uma escrita formal se integra ao gênero e ao discurso científicos como comportamento a ser adquirido, na verdade, continuamente desenvolvido". Podemos supor, de tal modo, que a aprendizagem da escrita acadêmica, no sentido de adquirir as especificidades de uma escrita característica de uma dada comunidade, corresponderia a um processo gradual, no qual o nível de conhecimento sistematizado e do grau de profundidade sobre as tradiçôes retóricas da comunidade, possuídos pelos sujeitos ingressantes, fazem toda a diferença.

Essas singularidades da escrita acadêmica estariam vinculadas aos padrôes discursivos presentes em cada gênero privilegiado por esse grupo. Segundo Wilson (2009), para que o aluno adquira a condiçấo letrada exigida pela universidade, ele precisa dominar a norma culta e incorporar os valores da academia e as práticas linguísticas e discursivas privilegiadas nesse contexto que, por sua vez, implicam a aprendizagem de competências para lidar com o saber fazer; interpretar e reinterpretar conceitos e verdades da cultura popular e da cultura acadêmica; e ajustar-se às condiçôes de produçăo dessa esfera.

Săo novas maneiras de compreender, interpretar e organizar o conhecimento, às quais os sujeitos devem se adequar. Essas maneiras năo estăo preestabelecidas no campo cognitivo dos sujeitos nem sâo adquiridas automaticamente no contato com o meio acadêmico pelo simples fato de terem passado no exame de ingresso. A apropriaçăo das práticas de escrita acadêmica requer múltiplas competências, "numa complexa inter-relaçăo entre aspectos linguísticos, cognitivos e socioculturais" (BEZERRA, 2012, p.247).

Na universidade, como sabemos, algumas dessas competências e habilidades náo sâo claras, devido a fatores diversos. Cada disciplina, cada evento comunicativo possui normas reguladoras cujas especificaçôes, por vezes, săo nebulosas para os alunos. 0 professor surge, entấo, como um sujeito importante nessa aprendizagem da escrita, desempenhando um papel de orientador, já aceito e reconhecido pelo grupo de pares 
(grupo de membros daquele ambiente acadêmico), que pode intermediar o aprendizado dos ingressantes.

Além disso, os gêneros textuais, como lembra Bazerman (2005), náo săo atemporais nem iguais para todos os observadores, uma vez que o conhecimento dito comum muda no decorrer do tempo, assim como mudam os gêneros e as situaçóes. Por isso, enfatiza esse autor (2005, p.31): "a definiçăo de gêneros como apenas um conjunto de traços textuais ignora as diferenças de percepçăo e compreensăo, o uso criativo da comunicaçáo [...] e a mudança no modo de compreender o gênero com o decorrer do tempo". Os gêneros săo mais que aspectos linguísticos, săo fenômenos de reconhecimento psicossocial, conforme o estudioso, pois sâo partes de processos de atividades socialmente organizadas.

Desse modo, a formaçăo superior visa, dentre outros objetivos, que os alunos se apropriem do discurso e das práticas de escrita acadêmica e, em consequência, do discurso acadêmico e das relaçóes sociais, exigindo, para isso, conforme Giudice e Moyano (2011), práticas linguísticas cada vez mais completas em relaçăo aos conteúdos, às atividades de pesquisa e à aplicaçăo na vida profissional.

Para estabelecer laços de pertencimento no grupo acadêmico, o graduando necessita, em síntese, aprender e dominar a escrita acadêmica, concretizada e articulada através dos gêneros característicos dessa comunidade, estabelecidos na e pela linguagem. Por conseguinte, há conhecimentos de diversas naturezas imbricados na produçâo de um texto especializado, ou seja, acadêmico, que devem ser levados em conta e aprendidos.

De acordo com Beaufort (1998 apud SWALES, 2009, p.35), cinco săo os domínios de conhecimento contextualizado para o texto especializado: (1) conhecimento do assunto, (2) conhecimento retórico, (3) conhecimento do processo de escrita, (4) conhecimento do gênero e (5) conhecimento da comunidade discursiva. A produçáo escrita que gera o texto especializado seria, assim, moldada pela sobreposiçâo dos quatro primeiros conhecimentos, que săo posteriormente

encapsulados ou envolvidos pelo que a autora chama de "conhecimento da comunidade discursiva" (p.64) [o que seria o quinto conhecimento], ou pelo que Ken Hyland (2000) chama de "culturas disciplinares", ou pelo que outros chamaram de "comunidade de prática" (LAVE; WENGER, 1991) ou talvez pelo que Bourdieu chama de "habitus" (BOURDIEU, 1991). (BEAUFORT, 1998 apud SWALES, 2009, p. 35).

Tardy (2009 apud BAWARSHI; REIFF, 2013, p.164), por sua vez, com base em textos de estudantes de pós-graduaçăo, descreveu as seguintes características multidimensionais de gêneros: (1) domínios de conhecimento formal, (2) conhecimento retórico, (3) conhecimento temático e (4) conhecimento processual.

Essas características de Tardy assemelham-se aos quatro domínios de conhecimentos apresentados por Beaufort, o que nos permite redefinir esses domínios, tornando-os mais sintéticos e com fronteiras mais nítidas de análise. Assim, redefinindo os domínios de conhecimento com base em Beaufort e Tardy temos: 


\section{Gráfico 2: Domínios de conhecimento contextualizado para o texto especializado}

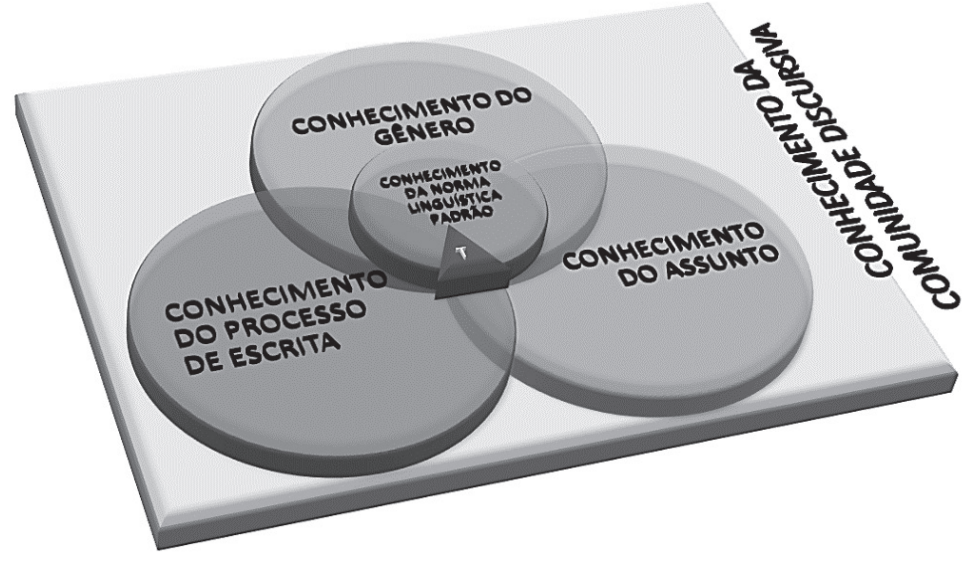

Fonte: Elaborado pelas autoras com base nos textos de Beaufort (1998 apud SWALES, 2009, p. 35) e de Tardy (2009 apud BAWARSHI; REIFF, 2013, p.164)

O conhecimento do assunto (círculo à direita), o conhecimento do gênero (circula acima), o conhecimento do processo de escrita (círculo à esquerda) săo os três conhecimentos bases para a produçâo de um texto especializado ("T" - triângulo resultante da interseçáo entre os conhecimentos), isto é, de um texto que circule proficientemente no meio para o qual foi produzido, sendo aceito como exemplar do gênero por seus interlocutores. Além desses conhecimentos, destacamos o conhecimento da norma linguística padrấo (círculo sob o conhecimento do gênero), que está dentro do conhecimento do gênero, que se evidencia devido a sua inegável importância na comunidade acadêmica, em especial num curso de Licenciatura em Letras. 0 conhecimento da comunidade discursiva (base para os outros conhecimentos) estaria em um nível distinto dos demais, já que seria um conhecimento formado pelos outros conhecimentos e dependente destes.

De acordo com os dados coletados para esta pesquisa, o conhecimento do assunto para as situaçóes de escrita focalizadas já estava dado, pois os assuntos foram previamente estudados em sala de aula antes das produçóes, o que implica dizer que os sujeitos já deveriam tê-los assimilado. 0 conhecimento do processo de escrita implica a própria montagem dos textos, nas idas e vindas do processo de escritura; portanto, para ser analisado profundamente necessita de acompanhamento que os nossos dados năo revelam por serem versōes finais dos gêneros. Restam o conhecimento do gênero e o conhecimento da comunidade discursiva, este último parece-nos ser o mais significativo, porque ele revela a importância de se pensar o texto como uma tessitura complexa de inter-relaçấo de aspectos que, juntamente com o conhecimento do gênero, permite a definiçáo da unidade retórica da análise como um elemento constitutivo e característico da escrita acadêmica.

Cada sujeito produtor tem "uma história particular e um conjunto atual de questôes de vida; um conjunto de compreensôes sobre escrita, sobre sociedade e sobre o assunto específico à măo; e um repertório de percepçôes retóricas, técnicas e habilidades" (BAZERMAN, 2007, p.55) e, quando reconhece uma situaçăo de escrita, constrói um enquadre para a açấo e busca recursos disponíveis para realizá-la. Esses recursos podem possuir naturezas diferenciadas e, segundo nossas observaçóes, se estiverem 
de alguma forma relacionados aos conhecimentos anteriormente apresentados podem levar ao texto especializado.

Essas reflexóes e contribuiçóes teóricas nos fazem pensar que, embora o aparente consenso de que as práticas discursivas presentes na comunidade acadêmica grupo influenciam todos os sujeitos, as influências dăo-se de maneira desigual e variável em decorrência da história de experiências sociais comunicativas de cada um. Isso porque os conhecimentos năo săo compartilhados homogeneamente por parte dos sujeitos.

Uma variável no compartilhamento dos conhecimentos é a "distância social" discutida por Bhatia (2009, p.185). Para o autor, o "conhecimento compartilhado do gênero [...] nâo é normalmente acessível a estranhos, o que cria uma espécie de distância social entre os membros legítimos da comunidade discursiva e aqueles que săo considerados como estranhos".

Embora o conhecimento compartilhado entre os membros de uma comunidade discursiva crie um "grupo", uma distância social é intensificada entre os membros efetivos e os năo membros. Esse distanciamento, a nosso ver, pode inibir a entrada de novos membros, sendo, essa uma das razóes da complexidade e opacidade do processo de aprendizagem da língua escrita que resulta na dificuldade de alunos produzirem textos, principalmente textos especializados.

A partir do exposto, podemos pensar a aprendizagem da língua escrita além dos processos de aquisiçăo do código. Em outras palavras, ao adotar a noçáo de aprendizagem da escrita, nâo estamos nos referindo apenas à aquisiçăo do código, pois o sujeito investigado já o adquiriu. Estamos investigando a aprendizagem em um sentido mais amplo, que envolve aspectos linguísticos, textuais e discursivos, característicos da escrita acadêmica e presentes nos gêneros textuais dessa esfera.

Assim, o licenciando, nesse processo de aprendizagem, năo pode ser considerado como receptor passivo de conhecimento (SCARPA, 2001), pois ele busca afirmar-se como sujeito da linguagem, como membro de uma comunidade discursiva, como construtor do seu próprio conhecimento de mundo passando pela representatividade do outro. Sua produçấo textual revela a aprendizagem dos conhecimentos anteriormente citados, conforme será demonstrado na seçăo a seguir.

\section{ESCREVENDO NO ENSINO SUPERIOR: O PERCURSO DE UM LICENCIANDO EM LETRAS}

As resenhas, o artigo científico e o relato de observaçăo analisados foram coletados em três disciplinas da grade curricular do curso de licenciatura e em um curso de férias. As disciplinas năo tinham a preocupaçăo explícita com o ensino de escrita. A análise dos dados apontou que os professores ministrantes das mesmas solicitaram os gêneros de acordo com o que julgavam necessário aos alunos e/ou, talvez, de acordo com as necessidades das disciplinas. Logo, a requisiçấo dos gêneros esteve muito mais centrada no professor, na sua disciplina e em seu projeto de ensino, do que no licenciando. Já o curso de férias, realizado entre o primeiro e o segundo períodos letivos, surgiu da preocupaçăo com o ensino de escrita e teve como objetivo melhorar a escrita do gênero acadêmico resenha, devido à constataçáo da dificuldade da turma na qual o licenciando estava matriculado em redigir textos desse gênero. 
Assim, a aprendizagem da escrita nesses quatro momentos observados náo se deu de maneira sistêmica, pensada conforme a complexidade dos gêneros e/ou dos conhecimentos que se queria desenvolver em cada período, com o objetivo de integrar as aprendizagens numa lógica processual. A partir desse contexto tăo recorrente em nossas instituiçôes de ensino superior, observar o percurso de um licenciando pode trazer reflexôes interessantes para o estudo da escrita acadêmica. Desse modo, apresentaremos, a seguir, consideraçôes sobre as produçôes investigadas tomando um fragmento representativo de cada texto (resenhas, artigo científico e relato de observaçăo).

\section{RESENHA 1 - PRIMEIRO PERÍODO LETIVO}

Duas foram as resenhas observadas. A primeira oriunda de disciplina no primeiro período letivo e a segunda do curso entre o primeiro e o segundo período, nas quais o sujeito cumpre, mesmo que com menor complexidade e com algumas parcialidades, a estrutura retórica básica do gênero: introduzir, sumarizar, criticar e concluir. Vejamos um fragmento significativo da resenha 1, com alguns destaques, seguido de apontamentos que sintetizam a análise.

\section{Fragmento 1: Resenha 1}
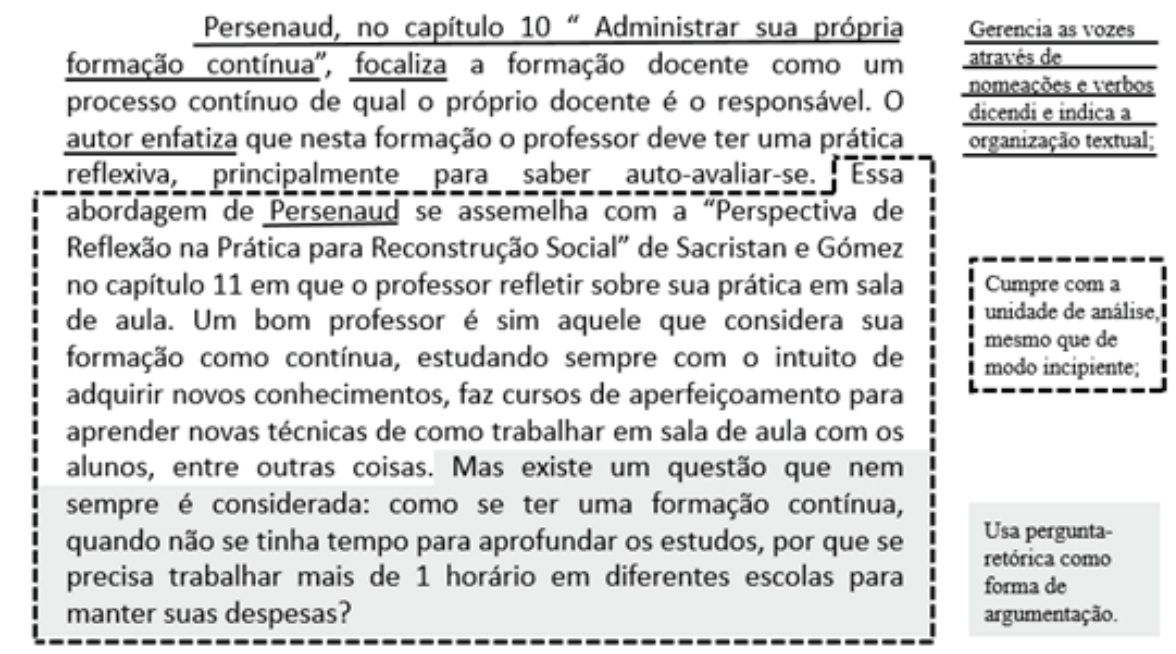

O sujeito, na produçâo da resenha 1, coloca-se, embora com limitaçôes, no papel de especialista, de membro da comunidade acadêmica, de autoridade que náo apenas descreve as obras lidas, mas, também, que tece comentários sobre elas, como podemos observar no fragmento, com destaque para o estabelecimento da relaçâo de semelhança entre o texto de Perrenoud e o texto de Sacristán e Pérez-Gómez, e a utilizaçáo do recurso argumentativo e persuasivo da pergunta retórica para levar seu leitor à reflexâo e, indiretamente, à adoçâo do seu ponto de vista. O uso da pergunta retórica indicia algum pouco conhecimento da comunidade discursiva acadêmica e do gênero, parece indicar a necessidade de argumentar e se posicionar, provavelmente, advinda da produçấo de gêneros como artigo de opiniăo, ainda no ambiente escolar, no qual esse tipo de recurso de argumentaçăo é mais usual.

Na resenha, em sua extensâo, há indícios, assim, de um sujeito, ainda năo membro, mas que busca tornar-se membro, apesar de suas limitaçôes, através do seu engajamento 
ao cumprir com a unidade retórica de análise, mesmo que de modo incipiente e, às vezes, prescritivo; ao expor-se como produtor do seu texto por meio da primeira pessoa do singular e do plural, sendo esta última também uma maneira de preservaçăo de face e de envolvimento com o leitor; ao retextualizar os textos-fonte e realizar o gerenciamento de vozes através de nomeaçóes (formas que fazem referência ao autor do texto-fonte, por exemplo: autor e Persenaud) e o uso de verbos dicendi (verbos "do dizer" usados para indicar a voz do autor, por exemplo: focaliza e enfatiza), como verificamos no fragmento; ao seguir uma organizaçăo textual, apesar de desvios à norma padrâo da língua. Essas açōes revelam o grau ainda inicial de consciência linguística e textual do sujeito em relaçấo ao gênero produzido e resenhado e do conhecimento da comunidade discursiva, bem como do seu conhecimento do conteúdo, do processo de escrita e da norma padráo.

\section{RESENHA 2 - SEM FÉRIAS PARA 0 ESTUDO}

Como já exposto, a resenha 2 foi produzida num curso de férias destinado ao aprimoramento da escrita acadêmica, com foco no gênero resenha, elaborado tendo como texto-fonte um texto já trabalhado em sala de aula, na disciplina Fundamentos da Prática Educativa, assim como os textos-fonte da resenha 1. Assim, partiu-se de texto já conhecido para que todas as atençóes se voltassem para as especificidades do gênero que seria escrito.

Observemos um fragmento significativo.

\section{Fragmento 2: Resenha 2}

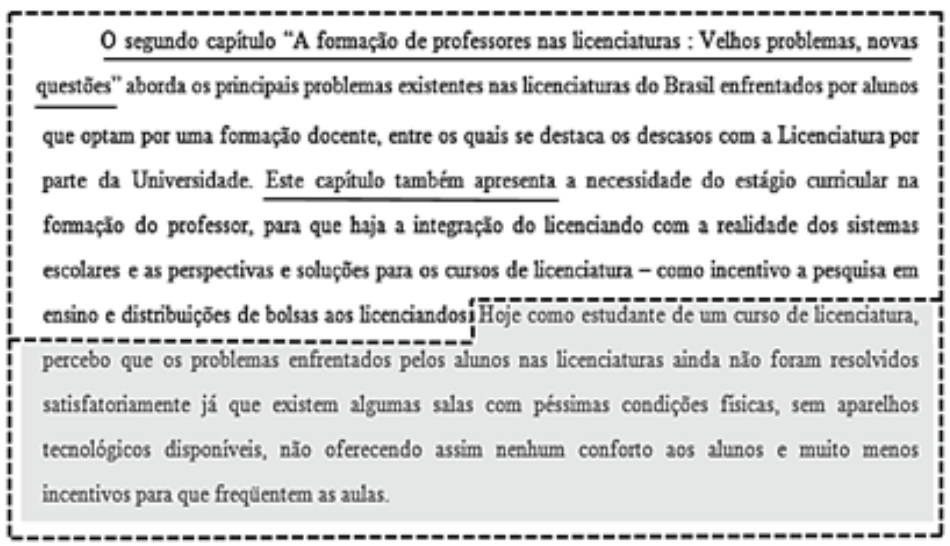

\begin{tabular}{|c|}
\hline $\begin{array}{l}\text { Gerencia as vozes e } \\
\text { indica a organização } \\
\text { textual; }\end{array}$ \\
\hline $\begin{array}{l}\text { Resume e comenta } \\
\text { cada texto-fonte } \\
\text { em um parágrafo; }\end{array}$ \\
\hline $\begin{array}{l}\text { Posiciona-se de } \\
\text { forma engajada e } \\
\text { não velada; }\end{array}$ \\
\hline $\begin{array}{l}\text { Relaciona texto- } \\
\text { fonte e sua } \\
\text { experiência (ainda } \\
\text { que velada); }\end{array}$ \\
\hline
\end{tabular}

O desenvolvimento dos conhecimentos inerentes à produçáo de texto especializado, evidenciado pelo sujeito em sua resenha 2, parece estar ligado à repetiçăo do exercício de escrever, à repetiçăo do gênero e à confirmaçăo de escolhas na produçấo por meio do curso. Essas repetiçôes e confirmaçōes centraram-se principalmente, como podemos verificar no fragmento apresentado, na organizaçaáo textual (recorrência da estrutura sumarizaçáo seguida de comentário) e no cuidado com o gerenciamento de vozes, que já eram vistos na resenha 1, e que o sujeito manteve na segunda resenha. Vale salientar, ainda, que o sujeito adquiriu mais autonomia escritora decorrente do aprimoramento dos conhecimentos da comunidade discursiva, do processo de escrita e do gênero, principalmente, no curso de férias. Essa autonomia é corroborada pela utilizaçăo de aspectos que denunciam o desenvolvimento da escrita acadêmica: título, 
modalizaçăo, comentários com base na relaçăo entre texto teórico lido e sua experiência como licenciando (ainda que velada), marcada pelo verbo em primeira pessoa do singular "percebo", também perceptível no fragmento.

\section{ARTIGO CIENTÍFICO - SEGUNDO PERÍODO LETIVO}

Diferentemente do gênero resenha acadêmica, como se sabe, o artigo científico possui comumente subdivisóes claras das suas unidades retóricas delimitadas por subtítulos. Diante desse fato e da nossa constataçăo inicial de que o comentário analítico seria o ponto de encontro entre os três gêneros observados e o elemento caracterizador da escrita acadêmica, apresentamos a seguir consideraçóes sobre a análise.

O sujeito intitulou seu artigo de A sociointeraçâo de Abdias com sua família em termos de enunciados concretos, cujo objetivo foi, conforme introduçăo do texto, "analisar as interaçōes de Abdias com sua família em termos de enunciado concretos no romance 'Abdias', de Cyro dos Anjos". Para cumprir com o objetivo proposto, o sujeito, por orientaçâo do professor da disciplina, compôs seu artigo científico de capa, resumo, introduçăo, fundamentaçăo teórica, análise e conclusăo, além das referências. Vejamos um fragmento da seçāo analítica do artigo científico.

\section{Fragmento 3: Artigo científico}

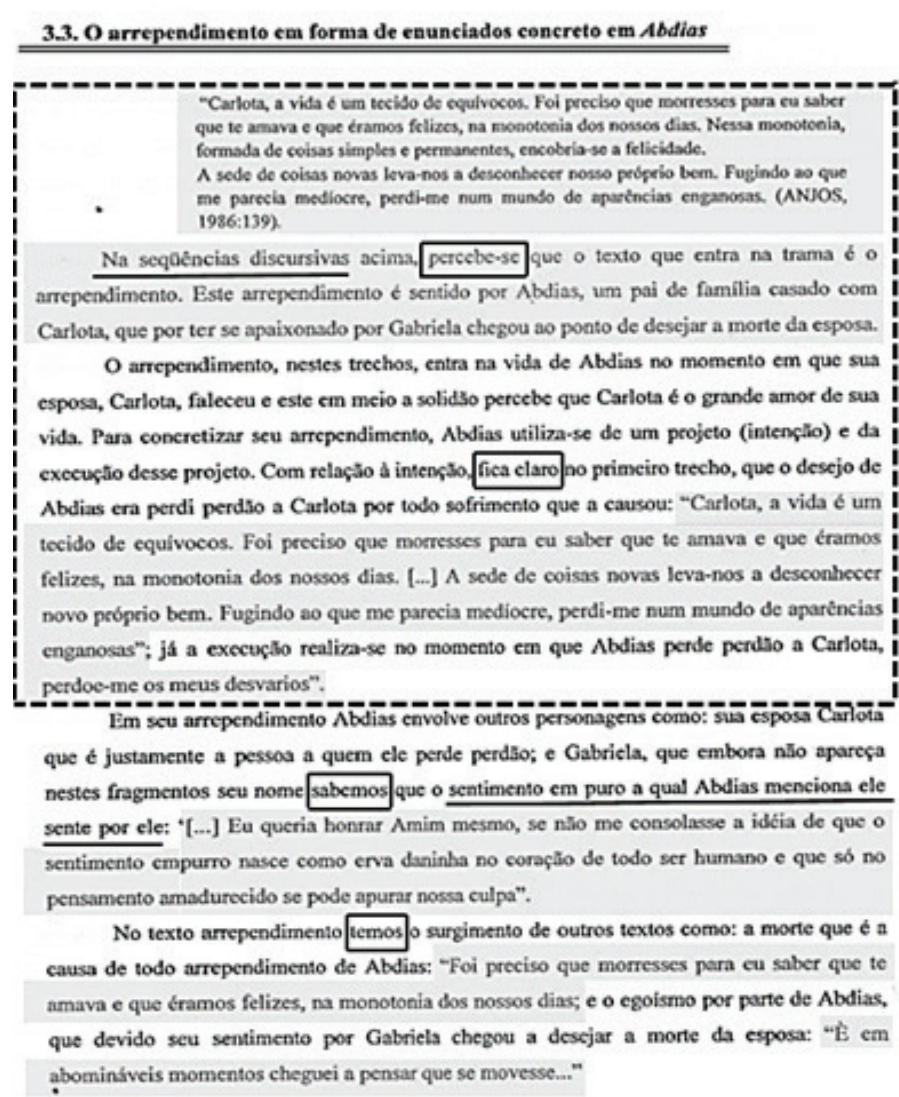

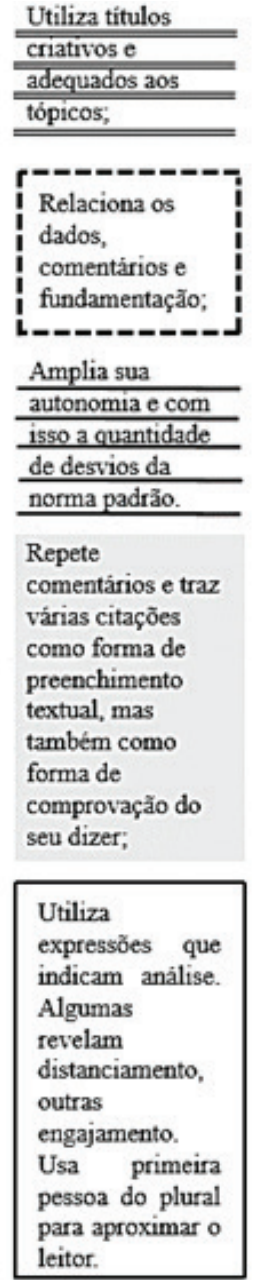


O modo organizacional da seçăo de análise do artigo científico aponta para um produtor engajado na comunidade discursiva, que percebeu a necessidade de relacionar os dados, comentários e fundamentaçáo, como podemos observar brevemente no fragmento apresentado. $\mathrm{O}$ sujeito organizou sua análise logicamente através de categorias e elaborando um tópico de fechamento para os tópicos categorizados, mostrando as relaçóes entre eles. Com isso, o licenciando demonstra estar amadurecendo seu conhecimento sobre o texto especializado, percebendo, conforme os dados evidenciam, que a escrita acadêmica requer análises alicerçadas, análises recursivas de ida e volta aos dados, a fim de (des)confirmar hipóteses. A estratégia de organizar a análise em seçóes definidas, como a parcialmente exposta no trecho acima, parece-nos ser adequada por permitir uma leitura mais objetiva e coerente, características importantes para um texto acadêmico. Todavia, o sujeito parece acomodar-se e fazer repetiçóes que empobrecem seu texto, como exemplo temos o primeiro parágrafo do fragmento, o qual é repetido em outras seçōes do artigo analisado. As repetiçôes sugerem, assim como as longas citaçóes do romance, o uso de estratégias de preenchimento textual, comuns em textos de iniciantes, e, além disso, podem ser vistas como respostas à necessidade de comprovar o que vem sendo dito no artigo pelo sujeito.

Verificamos também a presença de títulos criativos e adequados aos tópicos, a tentativa de uniformizaçâo dos tópicos analíticos e o uso linguístico adequado (tempos verbais e pessoas do discurso; expressôes indicativas de análise, por exemplo). Com essas estratégias, o sujeito demonstra estar desenvolvendo o domínio do conhecimento do gênero, do processo de escrita, do conteúdo e da comunidade discursiva, através de uma percepçấo analítica que se amplia juntamente com sua autonomia e sua busca para tornar-se membro.

Vemos a recorrência de expressóes que indicam a análise. Como podemos ter uma ideia por meio do fragmento, algumas revelam distanciamento do sujeito, outras indicam seu engajamento ao assumir-se como analista. Há ainda o uso do plural da primeira pessoa com a finalidade de envolver o leitor e chamá-lo para também analisar.

Por fim, salientamos que, proporcionalmente à ampliaçăo de sua autonomia, amplia-se também a quantidade de desvios quanto à norma linguística padrăo, como a expressáo "na sequências discursivas". O sujeito, ao adquirir maior confiança em sua escrita, arrisca-se mais em suas construçôes e, por produzir um gênero de maior extensáo do que as resenhas, evidencia mais problemas de domínio do conhecimento da norma padrâo que prejudicam a composiçăo textual. Há um baixo domínio do conhecimento da norma culta da língua por parte do sujeito que, muitas vezes, prejudica os bons comentários e as relaçóes que săo estabelecidas, principalmente nas unidades analíticas dos gêneros resenha e artigo científico, nas quais o sujeito está mais livre de textos-fonte para guiar sua escrita. Vale ressaltar que muitos desses problemas de concordância simples entre núcleo do sujeito e adjuntos adnominais, por exemplo, poderiam ter sido solucionados com a utilizaçăo do revisor de texto do próprio programa de computador utilizado para ediçăo do artigo científico.

A maior quantidade de erros/inadequaçóes no artigo científico e, também, no relato de observaçấo (discutido posteriormente) em relaçăo às resenhas, supomos que se deve ao fato de os gêneros serem mais analíticos, como já dito, maiores em extensăo, e o sujeito se sentir mais livre para escrever. Em outras palavras, se há mais escrita, há, 
proporcionalmente, mais erros e, se o sujeito sente-se mais livre para escrever, ele se arriscará mais, tanto em formas linguísticas quanto em tentativas de posicionamento.

\section{RELATO DE OBSERVAÇĀO - TERCEIRO PERÍODO LETIVO}

O relato de observaçăo, elaborado pelo sujeito, compóe-se de introduçăo, metodologia, fundamentaçăo teórica, descriçâo das observaçôes, consideraçôes finais e referências, cumprindo, assim, com a estrutura retórica prototípica. O gênero foi produzido no terceiro e último período letivo analisado, após a observaçăo feita pelo sujeito de aulas do ensino básico em escola regular.

Ao investigarmos a unidade de análise do relato, denominada "Descriçâo das observaçōes", observamos manutençôes e modificaçóes de conhecimentos demonstrados pelo sujeito nas produçōes anteriores. Vejamos, a seguir, um fragmento significativo desse relato.

\section{Fragmento 4: Relato de observaçáo}

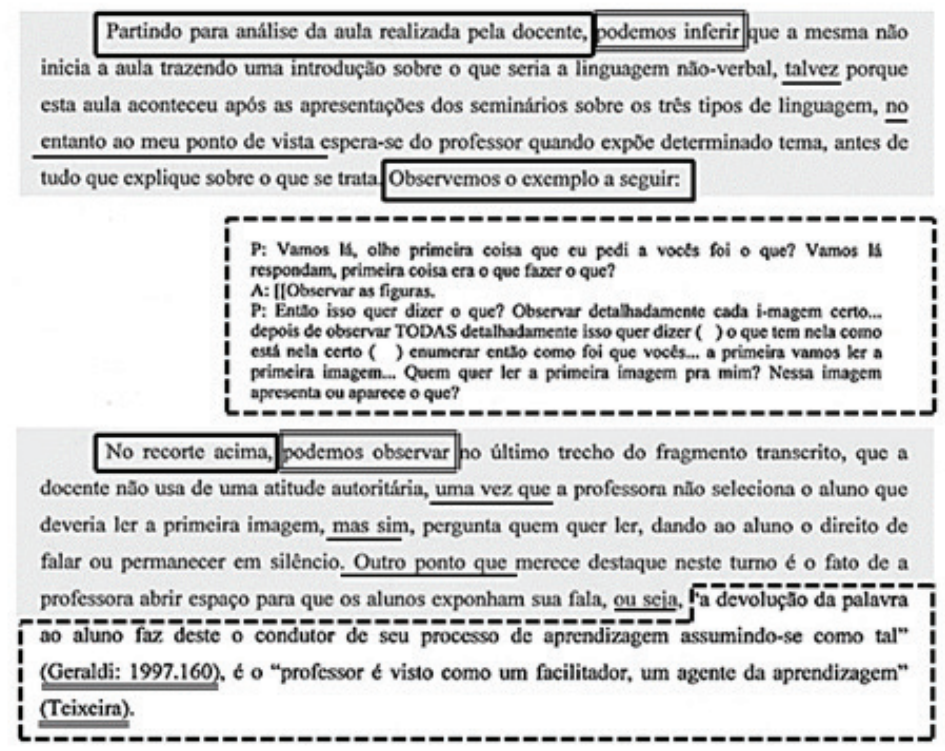

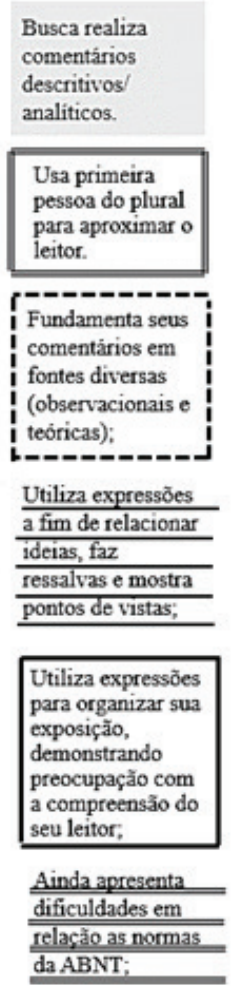

Observamos que o relato apresenta verbos na primeira pessoa do plural e também expressōes que indicam primeira pessoa do singular. Essa ocorrência já havia se dado anteriormente e repete-se novamente, o que pode indicar tanto falta de monitoramento do texto, que sugere pouco conhecimento relativo ao processo de escrita, já que o sujeito năo revisou seu texto, a fim de padronizar as formas verbais; quanto falta de conhecimento do gênero, por se tratar de um relato, o uso deveria ser da primeira pessoa do singular. A análise dos dados nos leva a ver que essa mudança é decorrente de pouco domínio do conhecimento do processo de escrita. Como já dito ao tratarmos do artigo científico, o sujeito tende, por ser um texto de maior extensáo, a cometer mais inadequaçôes linguísticas, problema que seria solucionado com uma reescrita. 
Em contrapartida ao uso da primeira pessoa do plural, no primeiro parágrafo do fragmento, o sujeito expôe-se ao utilizar a expressâo "ao meu ponto de vista". A forma de argumentaçăo usada nesse parágrafo é interessante do ponto de visto do desenvolvimento da escrita acadêmica, vejamos novamente o parágrafo: "Partindo para análise da aula realizada pela docente, podemos inferir que a mesma nâo inicia a aula trazendo uma introduçâo sobre o que seria a linguagem nâo-verbal, talvez porque esta aula aconteceu após as apresentaçôes dos seminários sobre os três tipos de linguagem, no entanto ao meu ponto de vista espera-se do professor quando expóe determinado tema, antes de tudo que explique sobre o que se trata. Observemos o exemplo a seguir.".

No parágrafo reproduzido acima, inicialmente, o sujeito afirma, em primeira pessoa do plural, que a professora deixa de realizar uma introduçấo (em itálico); após, utiliza o "talvez" como modalizador para fazer uma ressalva que possivelmente explicaria a atitude da professora (sublinhado); em seguida, faz uso da conjunçâo adversativa "no entanto" para colocar seu comentário sobre o fato, que se opóe à possível explicaçâo para a açâo da professora, deixando claro que o posicionamento é seu através da expressăo "ao meu ponto de vista" (em negrito); por fim, utiliza o verbo "observemos" no imperativo/primeira pessoa do plural para comprovar seu posicionamento por meio de uma transcriçáo.

Com isso, o sujeito revela conhecimento de análise, pois mostra o fato, faz suposiçōes que o justificariam, coloca sua opiniăo, e, o mais interessante, uma opiniâo baseada, possivelmente, na experiência pessoal que se opóe ao fato narrado. Apesar dessa demonstraçáo de desenvolvimento do conhecimento da comunidade discursiva, o sujeito, por ainda encontrar-se num estágio em que busca ser aceito nessa comunidade, pede que o leitor confirme seu posicionamento através da observaçăo de uma transcriçăo da aula.

No relato de observaçăo, em suma, verificamos demonstraçôes de desenvolvimento do conhecimento da comunidade discursiva, do gênero, do processo de escrita e do conteúdo, através de indícios presentes na seção analítica. O sujeito demonstra seu posicionamento, faz comentários mais fundamentados e embasados em fontes diversas (teóricas e observacionais), como verificamos no fragmento, utiliza conectivos a fim de relacionar ideias, organiza sua exposiçâo de acordo com critérios e demonstra se preocupar com a compreensáo do seu leitor, faz ressalvas e mostra pontos de vistas positivos e negativos, começa a apresentar citaçóes indiretas. Em compensaçăo, o sujeito comete inadequaçóes micro e macroestruturais, apresenta dificuldade de seguir normas de citaçấo e referenciaçáo estabelecidas pela ABNT, nâo exibe uma padronizaçăo da pessoa do discurso utilizada.

O sujeito, portanto, busca inserir-se na comunidade discursiva acadêmica através de vários conhecimentos inerentes à escrita característica dessa comunidade, mesmo sem grande domínio da norma padrăo da língua, que também é uma característica essencial da escrita acadêmica. Parece-nos que o seu esforço é o de desenvolver o domínio dos outros conhecimentos, mas náo o da escrita padrăo. Talvez, o sujeito, dê maior atençấo às demonstraçôes dos conhecimentos relativos ao gênero, comunidade discursiva e assunto em detrimento ao conhecimento da norma padrăo, contudo, dominá-la é uma exigência implícita nos outros conhecimentos da comunidade referida, nâo dominá-la revela uma lacuna que remonta ao ensino básico. O desconhecimento da norma prejudica o andamento da análise, deixa o texto truncado e dificulta a aceitaçấo desse sujeito pelos demais membros da comunidade. 


\section{DO PRIMEIRO AO TERCEIRO PERÍODO - O QUE DIZER DESSE PERCURSO?}

A análise brevemente exposta valida a tese inicial de que a aprendizagem da escrita acadêmica se dá por meio da aprendizagem e/ou aprimoramento do domínio dos gêneros típicos dessa esfera discursiva por parte do sujeito. Em outras palavras, a escrita acadêmica materializa-se nos gêneros textuais típicos desse meio, cuja aprendizagem é decorrente da inserçâo do sujeito como membro dessa esfera e também da manifestaçâo do conhecimento dos gêneros que nela sâo mobilizados por membros mais experientes e já iniciados. Tanto a inserçâo quanto o conhecimento dos gêneros estăo interligados e evidenciam o domínio de conhecimentos para o texto especializado; por sua vez, a demonstraçăo desses conhecimentos aponta para as etapas de imersăo do sujeito produtor na comunidade discursiva, isto é, a aceitaçâo/reconhecimento deste como membro.

Ao analisarmos os dados, identificamos, inicialmente, que os conhecimentos e as etapas estariam relacionados à construçâo da unidade retórica de análise presente em cada um dos três gêneros (e em diversos outros gêneros textuais tipicamente acadêmicos), cada um deles com suas especificidades, mas interligados por esse eixo comum e caracterizador da escrita dessa comunidade discursiva. E por meio dessa unidade que o sujeito produtor do texto posiciona-se como membro, de acordo com uma determinada base teórica e para análise de um dado, visando, com isso, cumprir com o objetivo comunicativo dos gêneros e ser aceito como membro da comunidade. $O$ sujeito focalizado, apesar de dificuldades e mesmo sem total domínio da produçấo textual, busca apresentar a unidade retórica da análise em suas produçóes e, assim, ser reconhecido entre os pares. Isto nos faz pensar que o processo de aprendizagem da escrita seria também decorrente de empenho pessoal do licenciando, mas năo apenas deste.

A unidade analítica na academia parte, muitas vezes, da síntese ou do relato, por exemplo, mas náo se limita a isso, a análise implica em fundamentar, justificar, argumentar, persuadir, relacionar, inferir, comparar, averiguar, explorar, criticar etc. Essa complexa e multifacetada unidade retórica requer abstraçăo e subjetividade para demonstrar o que năo é explícito objetivamente, logo, é um tipo de raciocínio que precisa ser iniciado e treinado, além de requerer conhecimentos do aparato linguístico-textual para concretizá-la.

Em termos de conhecimentos, săo esperados, no primeiro período letivo, problemas e dificuldades, por parte do sujeito investigado, relacionadas ao resumo e ao comentário de capítulos de livros teóricos, experiência até entâo inédita. No segundo período, verificamos a superaçăo de alguns problemas e o surgimento de outros; nesse sentido, a produçấo das resenhas parece ter auxiliado a produçăo da fundamentaçăo teórica do artigo científico, mas, além disso, o sujeito se deparou com a necessidade de elaborar análises fundamentadas de dados. No terceiro período, ao passar pela produçâo das resenhas e do artigo científico, supostamente encontramos a superaçâo das dificuldades na análise da situaçâo e sua correlaçāo com fundamentos teóricos.

Ao analisarmos os quatro textos do sujeito, com foco na seçâo analítica, verificamos que o processo de aprendizagem de escrita na academia está ligado, como já apontado, ao conhecimento do assunto, conhecimento do gênero, conhecimento da norma linguística padrăo, conhecimento do processo de escrita, conhecimento da comunidade discursiva, além de outro conhecimento identificado a partir dos dados - o conhecimento da informática básica. 
Os dados nos levam a crer que, para a aprendizagem da escrita acadêmica, o domínio linguístico e de editores de texto é indispensável. Convencionou-se pensar que por os alunos integrarem a geraçấo y e $z$ (terem nascido imersos num mundo digital) dominam o uso das tecnologias, contudo, as produçóes do sujeito investigado revelam que ele năo domina recursos básicos de editores de texto como Word, recursos de revisăo e também editoraçăo que poderiam solucionar problemas de ortografia e alguns de sintaxe, além de paragrafaçấo e citaçăo. Se o sujeito tivesse o domínio desse conhecimento, certamente, seus textos trariam menos indícios de aquisiçáo de escrita acadêmica. Utilizá-lo também seria uma maneira de o próprio sujeito refletir sobre seus textos. Esse conhecimento de informática deveria ser construído no ensino médio, em aulas de informática, nas quais estratégias de pesquisa em sites de busca e a elaboraçăo de referências e formas de citaçăo também poderiam ser abordadas como forma de prevenir o plágio.

Assim, os dados apontam para o ensino básico e para o ensino superior, numa via de máo dupla. De um lado, o ensino básico năo está cumprindo o seu papel de ensino da textualidade e de informática básica. Do outro lado, é papel do ensino superior, num curso de Licenciatura, sobretudo Letras, promover um processo de ensino organizado e assistido de gêneros acadêmicos, pois, como os dados levam a crer, é preciso admitir que alunos egressos da educaçăo básica, que chegam à licenciatura, ainda desconhecem processos básicos de organizaçăo e de progressâo textual.

De maneira geral, alguns conhecimentos investigados aparecem mais explicitamente nos dados devido à recorrência, outros săo menos perceptíveis; talvez isto se dê em decorrência de esta investigaçâo ter analisado versôes finais das produçôes. Os dados demonstram que náo houve fuga quanto ao conhecimento do assunto nem do gênero, já em relaçăo ao conhecimento do processo de escrita, da norma linguística, da informática e da comunidade discursiva observamos uma atitude que parece ter influenciado diretamente na aprendizagem da escrita desse sujeito: o engajamento.

O sujeito, no seu processo de aprendizagem, apesar de ainda năo membro da comunidade focalizada e de algumas limitaçóes, busca tornar-se membro, por meio do seu engajamento. Desde o primeiro período letivo, coloca-se no papel de especialista, assumindo-se como autor e apresentando sequências analíticas em seus textos, mesmo que de modo incipiente. No decorrer das produçóes, vai confirmando e aprimorando estratégias utilizadas e demonstrando que está adquirindo outras. Assim, a aprendizagem dos conhecimentos inerentes à produçâo de texto especializado, evidenciado pelas produçóes do sujeito, dá-se, em parte, de modo empírico, pela repetiçăo do exercício de escrever e pela confirmaçăo de escolhas linguísticas na produçâo.

Ao passo que se engaja nas produçōes, através de uma percepçăo analítica que se amplia juntamente com sua busca para se tornar membro, o sujeito que aqui focalizamos vai adquirindo a autonomia escritora decorrente do aprimoramento dos conhecimentos da comunidade discursiva, do processo de escrita, do assunto e do gênero. Em decorrência dessa autonomia, suas análises começam a ganhar mais relaçōes, comentários e fundamentaçōes; em contrapartida, amplia-se também a quantidade de desvios quanto à norma linguística padrăo. Esse sujeito, ao adquirir maior confiança em sua escrita, arrisca-se mais em suas construçōes e, em gêneros mais extensos, demonstra mais problemas de domínio do conhecimento da norma padrâo que prejudicam sua composiçâo textual. Dessa forma, os dados revelam que esse sujeito busca ser aceito na academia 
por meio de vários conhecimentos inerentes à escrita nessa comunidade, mesmo sem dominar a norma padrâo da língua e programas de ediçáo de texto que poderiam auxiliar na soluçăo de problemas de ortografia e sintaxe (em casos mais simples).

Assim, em seu processo de aprendizagem, o sujeito evidencia o aprimoramento dos conhecimentos. Conhecimento do assunto, do gênero, do processo de escrita e da comunidade discursiva se mostram quando ele generaliza sobre o tópico comum aos textos e/ou aos dados analisados; retextualiza; organiza o texto seguindo determinada ordem e/ou categorias de análise; intitula os textos e seus tópicos. O conhecimento do assunto, do gênero e da comunidade discursiva também sâo demonstrados quando realiza comentários, reformulaçôes, comparaçôes, julgamentos e estabelece relaçōes; bem como ao assumir-se como produtor do seu texto por meio de expressóes e de formas verbais; ao fundamentar-se em aspectos teórico ou prático, ou seja, quando ancora seu texto. Conhecimento do gênero, do processo de escrita e da comunidade discursiva se mostram quando o sujeito gerencia as vozes do texto; utiliza pergunta retórica; cumpre as unidades retóricas; modaliza; utiliza estratégias de pessoalidade e impessoalidade; usa termos teóricos. E o conhecimento da norma linguística padrâo foi demonstrado de modo incipiente, assim como o conhecimento da informática básica.

Em síntese, os conhecimentos relativos à norma linguística e aos recursos de editores de texto (informática básica), que auxiliariam na correçăo de aspectos da norma, năo sâo devidamente aprendidos nos três primeiros períodos letivos do sujeito investigado, ao passo que os conhecimentos relativos ao domínio da textualidade e do discurso parecem ser os que se consolidam como aprendidos no período focalizado. Assim, à semelhança de uma balança, conforme demonstrado na figura a seguir, os conhecimentos do segundo tipo parecem pesar a favor da inserçăo do sujeito na esfera acadêmica.

Figura: Conhecimentos normativos e conhecimentos textuais e discursivos

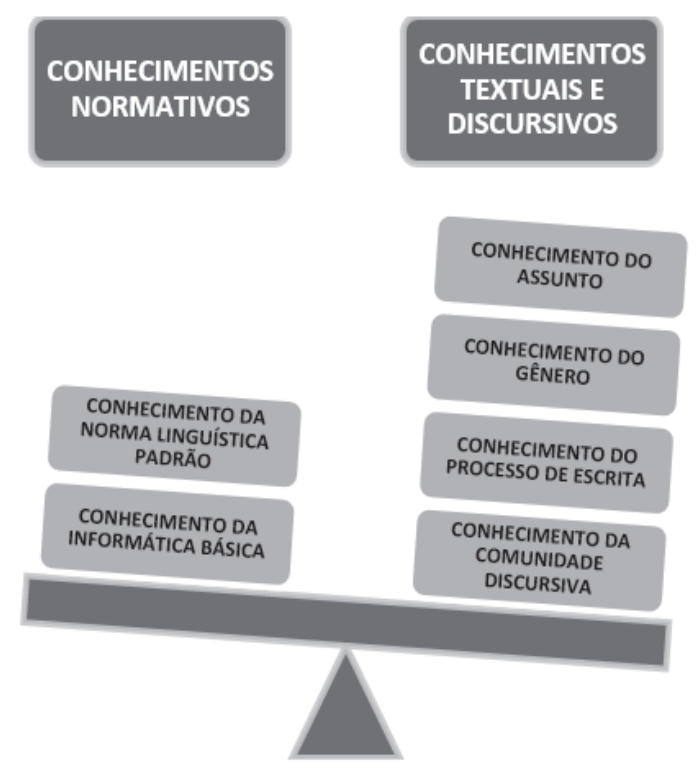

Fonte: Elaborada pelas autoras. 


\section{CONSIDERAÇÕES FINAIS}

A aprendizagem da escrita é um processo importante em contextos iniciais de ensino de escrita, que também pode ser observado no ensino superior, mas com foco diferenciado: a aprendizagem de especificidades da escrita acadêmica em gêneros específicos, que precisam ser aprendidas nesse nível de ensino, por estarem ligadas ao domínio de determinados conhecimentos, e a aprendizagem da língua escrita padrâo, nâo totalmente aprendida na educaçăo básica.

Tomando essa constataçăo como ponto de partida, neste artigo, através do relato sucinto de investigaçăo longitudinal, respondemos à questăo de pesquisa (que conhecimentos para o texto especializado săo mobilizados no processo de aprendizagem da escrita acadêmica materializada nos gêneros textuais acadêmicos resenha, artigo científico e relato de observaçăo?), e, consequentemente, cumprimos com o objetivo proposto(identificar e analisar os conhecimentos para o texto especializado mobilizados no processo de aprendizagem da escrita acadêmica materializada nos gêneros textuais acadêmicos resenha, artigo científico e relato de observaçâo, produzidos por um sujeito licenciando em Letras) quando apontamos a presença dos conhecimentos do assunto, do gênero, da norma linguística padráo, do processo de escrita, da informática e da comunidade discursiva, sendo este último resultante do domínio dos demais conhecimentos e, logo, caracterizador da unidade retórica da análise, que é comum a todos esses gêneros. Esses conhecimentos foram identificados e analisados através da investigaçăo de duas resenhas, um artigo científico e um relato de observaçâo, produzidos pelo sujeito licenciando. Verificamos, assim, que é fundamental para a aprendizagem da escrita acadêmica o desenvolvimento/aprimoramento desses conhecimentos, que estấo relacionados a etapas de aceitaçăo do sujeito produtor do texto como membro da comunidade discursiva acadêmica.

A pesquisa levou-nos a algumas implicaçôes. Verificamos que, de fato, parece haver a necessidade de ensino assistido e sistematizado da escrita acadêmica. Os professores ministrantes das três disciplinas cursadas pelo sujeito propuseram atividades de escrita, conforme os dados indiciaram, de acordo com o que eles supuseram ser a necessidade dos alunos ao escrever ou, talvez, de acordo com as necessidades das disciplinas que ministravam. A solicitaçâo dos gêneros năo teve como objetivo ensinar a escrever na academia, mas, objetivava cumprir determinadas atividades de disciplinas. Todavia, reconhecemos que houve aprendizagem de aspectos relacionados à escrita acadêmica a partir desses exercícios de escrita.

O ensino assistido, como propomos, poderia ser realizado tanto em cursos a parte, como o curso de férias do qual coletamos a resenha 2 , quanto pelo próprio docente da disciplina que, ao requerer a atividade, seja ele também o responsável por ensinar a escrever o gênero (seja qual for) numa perspectiva processual. Desse modo, a solicitaçăo do gênero sem retorno ao licenciando (ou o retorno com indicaçóes superficiais) nâo traz resultados tăo significativos como um trabalho orientado, no qual a reescrita coletiva em sala de aula torna-se imprescindível, pois é a oportunidade de sanar uma gama de dúvidas e, em decorrência, de desenvolver/aprimorar uma gama de conhecimentos sobre a escrita acadêmica.

Os cursos de escrita acadêmica como o registrado têm um papel importante, mas náo tăo decisivo quanto parece ser a reescrita do gênero solicitado liderada pelo próprio 
professor que demandou ou por um trabalho individual com os aprendizes feito por monitores. O professor surge, entáo, como um sujeito importante nessa aprendizagem da escrita, desempenhando um papel de orientador. Lembramos que esse papel foi ressaltado pelo sujeito quando se referiu a um professor que solicitava produçóes, mas nâo orientava a elaboraçấo das mesmas.

Em conclusăo, a pesquisa realizada mostrou que a aprendizagem da escrita acadêmica parece ser um processo complexo e multifacetado ainda pouco estudado. É um campo de investigaçáo fértil e relevante, tanto para o estudo de questôes teóricas quanto para questóes aplicadas. Este artigo centrou-se nas produçóes de um licenciando em Letras, todavia, vários elementos dessa rede discursiva ainda merecem destaque, como as etapas de aprendizagem de escrita acadêmica que estâo atreladas à aceitaçấo do sujeito produtor do texto como membro da comunidade discursiva acadêmica, o que nos leva a um outro trabalho. 


\section{REFERÊNCIAS}

BAWARSHI, A. S.; REIFF, M. J. Gênero: história, teoria, pesquisa, ensino. Traduçăo Benedito Gomes Bezerra et al. 1 ed. Săo Paulo: Parábola, 2013.

BEZERRA, B. G. A resenha acadêmica em uso por autores proficientes e iniciantes. In: BIASI-RODRIGUES, B.; ARAÚJO, J. C.; SOUSA, S. C. T. (Orgs.). Gêneros textuais e comunidades discursivas: um diálogo com John Swales. Belo Horizonte: Autêntica Editora, 2009.

BEZERRA, B. G. Letramentos acadêmicos na perspectiva dos gêneros textuais. Fórum Linguístico, Florianópolis, v. 9, n. 4, pp. 247-258, out./dez, 2012. Disponível em: <http:// dx.doi.org/10.5007/1984-8412.2012v9n4p247>. Acesso em: 22 mar. 2013.

BHATIA, V. K. A análise de gêneros hoje. In: BEZERRA, B. G.; BIASI-RODRIGUES, B.; CAVALCANTE, M. M. (Orgs.). Gêneros e sequências textuais. Recife: Edupe, 2009.

BIASI-RODRIGUES, B.; HEMAIS, B.; ARAÚJO, J. C. Análise de gêneros na abordagem de Swales: princípios teóricos e metodológicos. In: BIASI-RODRIGUES, B.; ARAÚJO, J. C.; SOUSA, S. C. T. Gêneros textuais e comunidades discursivas: um diálogo com John Swales. Belo Horizonte: Autêntica Editora, 2009.

BONINI, A.; FIGUEIREDO, D. C. Letramento e escrita acadêmica: uma experiência com o artigo de pesquisa. In: TFOUNI, L. V. (Org.). Letramento, escrita e leitura: questôes contemporâneas. Campinas-SP: Mercado de Letras, 2010.

BAZERMAN, C. Gêneros textuais, tipificaçăo e interaçăo. Săo Paulo: Cortez, 2005.

Gênero, Agência e Escrita. Săo Paulo: Cortez, 2006.

Escrita, Gênero e Interaçăo social. Săo Paulo: Cortez Editora, 2007.

BRONCKART, J-P. Atividade de linguagem, discurso e desenvolvimento humano. Campinas, SP: Mercado de Letras, 2006.

GIUDICE, J.; MOYANO, E. Apropiación del discurso de la economia: análisis evolutivo de um caso. In: BARBARA, L.; MOYANO, E. (Orgs.). Textos e linguagem acadêmica: exploraçôes sistêmicas funcionais em espanhol e português. Campinas-SP: Mercado de Letras, 2011.

MILLER, C. Estudos sobre: gênero textual, agência e tecnologia. Recife: Ed. Universitária da UFPE, 2009.

MOTTA-ROTH, D. Rhetorical features and disciplinary cultures: a genre-based study of academic book reviews in linguistics, chemistry and economics. Tese (Doutorado em Linguística) - Universidade Federal de Santa Catarina, Florianópolis, 1995.

MOTTA-ROTH, D; HENDGES, G. R. Produçăo textual na universidade. Săo Paulo: Parábola Editorial, 2010.

SCARPA, E. M. Aquisiçâo da Linguagem. In: MUSSALIM, F.; BENTES, A. C. (Orgs.). Introduçăo à linguística: domínios e fronteiras. Sâo Paulo: Cortez, 2001.

SILVA, J. R. Relato de Experiência Didática: elementos para a descriçāo e ensino do gênero. 90f. Dissertaçáo de Mestrado (Mestrado em Linguística). - Universidade Federal da Paraíba - UFPB. Joâo Pessoa, Paraíba. 2002. 
SWALES, J. M. Genre analysis: English in academic and researching setting. Cambridge: Cambridge University Press, 1990.

Sobre modelos de análise do discurso. In: BIASI-RODRIGUES, B.; ARAÚJO, J. C.;

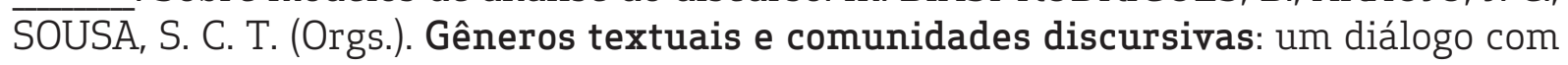
John Swales. Belo Horizonte: Autêntica Editora, 2009.

UAL. Projeto Pedagógico Curso de Licenciatura em Letras: Língua Portuguesa. Centro de Humanidades - CH. Unidade Acadêmica de Letras - UAL. Universidade Federal de Campina Grande - UFCG, 2011.

WILSON, V. A construçāo discursiva e identitária na escrita acadêmica. In: ALMEIDA, F. A.; GONÇALVES, J. C. (Orgs.). Interaçăo, contexto e identidade em práticas sociais. Niterói, RJ: Eduff. 2009. 